\title{
TDG Gene
}

National Cancer Institute

\section{Source}

National Cancer Institute. TDG Gene. NCI Thesaurus. Code C101583.

This gene is involved in catalyzing DNA repair. 